\title{
Concentration of oxytocin receptors in the placenta and fetal membranes of cows during pregnancy and labour
}

\author{
A-R. Fuchs ${ }^{1}$, H. Helmer ${ }^{1}$, S. M. Chang ${ }^{2}$ and M. J. Fields ${ }^{2}$ \\ ${ }^{1}$ Department of Obstetrics and Gynecology, Cornell University Medical College, New York, NY \\ I0021, USA; and 2 Animal Science Department, University of Florida, Gainsville, FL 32611, USA
}

\begin{abstract}
Summary. The concentrations of oxytocin receptors were measured in intercaruncular and caruncular endometrium, fetal cotyledons, chorioallantois and amnion during pregnancy and parturition in cows. Tissues were obtained on days 20 (endometrium only), 50,100,150,200,225,250, 275, at term (days 280-284), during labour and within $24 \mathrm{~h}$ after calving. Receptor concentrations in intercaruncular endometrium were low on day 20 of pregnancy, $39 \pm 11 \mathrm{fmol} \mathrm{mg}^{-1}$ protein. By day 50 , receptor concentrations had increased more than tenfold to $572 \pm 52 \mathrm{fmol}$ and rose steadily until day 250 and then levelled off at about $4500 \mathrm{fmol} \mathrm{mg}^{-1}$. Shortly before parturition, on day $282 \pm 1$, a further rise to $7300 \pm 1418 \mathrm{fmol} \mathrm{mg}^{-1}$ was observed, these concentrations were maintained throughout labour. By contrast, caruncular endometrial receptor concentrations remained low until term, mean $145 \pm 15 \mathrm{fmol} \mathrm{mg}^{-1}$, and then rose to $720 \pm 163 \mathrm{fmol} \mathrm{mg}^{-1}$ during labour (cervix $17 \mathrm{~cm}$ - fully dilated). Fetal cotyledons and membranes had very low oxytocin receptor concentrations during most of pregnancy, on average only $20 \mathrm{fmol} \mathrm{mg}^{-1}$ protein. At term and during labour, receptor concentrations were significantly increased in both tissues. Mean concentrations during labour were $163 \pm 36 \mathrm{fmol} \mathrm{mg}^{-1}$ for cotyledons, $270 \pm 61 \mathrm{fmol} \mathrm{mg}^{-1}$ for chorioallantois and $311 \pm 121 \mathrm{fmol} \mathrm{mg}^{-1}$ for amnion. The affinities of the oxytocin binding sites in the cotyledons and caruncular endometrium were similar and significantly higher than in the other tissues (caruncles and cotyledons, mean $K_{\mathrm{d}}$ : $5 \cdot 70 \times 10^{-10} \mathrm{~mol} \mathrm{l}^{-1}$; versus intercaruncular endometrium, $K_{\mathrm{d}} 9 \cdot 15 \times 10^{-10} \mathrm{~mol}^{-1}$ or fetal membranes, mean $K_{\mathrm{d}} 8.50 \times 10^{-10} \mathrm{~mol} \mathrm{l}^{-1}, P<0.001$ and $<0.005$, respectively). Receptor affinity did not change during gestation in any of the tissues. The steep rise in oxytocin receptor concentrations in fetal membranes, placentomes and endometrium shortly before and during parturition of cows suggests a role for oxytocin in addition to its contractile effect on the myometrium. Oxytocin receptors in these tissues probably mediate prostanoid release which in turn results in enhancement of the contractile effects of the hormone. The low caruncular oxytocin receptor concentrations may prevent the onset of labour before term despite the high concentrations of oxytocin receptors in the intercaruncular endometria during the last trimester of pregnancy.
\end{abstract}

Keywords: oxytocin receptor; pregnancy; parturition; endometrium; placenta; fetal membranes; cow

\section{Introduction}

Oxytocin receptors are present in the endometrium and myometrium of many species. The concentrations are high during parturition in all species studied (reviewed in Fuchs, 1985). Myometrial receptor occupancy causes contractions by increasing intracellular free calcium (Mironneau, 1976), and endometrial oxytocin receptor occupancy results in increased arachidonic acid metabolism and 
prostaglandin synthesis (Roberts et al., 1976). This dual action of oxytocin appears to be indispensable for parturition to proceed, at least in humans (Fuchs, 1990). In rats, rabbits and hamsters the receptor concentrations are regulated by ovarian hormones: oestrogen increases and progesterone inhibits oxytocin receptor formation (Soloff, 1975; Nissenson et al., 1978; Fuchs et al., 1983; Leavitt, 1985). The myometrial oxytocin receptor concentrations in these species are very low during gestation and rise shortly before the onset of labour when the ratio plasma oestradiol: progesterone increases (Soloff et al., 1979; Leavitt, 1985; Riemer et al., 1986). In cows (Fuchs et al., 1991; Jenner et al., 1991), as in humans (Fuchs, 1990), uterine oxytocin receptor concentrations are suppressed in early pregnancy, before and during the embryonic attachment, but begin to rise soon thereafter and surpass oestrous levels in the second and third trimesters despite relatively constant maternal plasma progesterone concentrations (Fuchs et al., 1992). The uterine response to oxytocin stimulation increases during pregnancy in cows (Fitzpatrick, 1960) in a parallel manner with oxytocin receptor concentrations suggesting that the receptors are functionally coupled to their effectors during pregnancy. Because oxytocin secretion from the posterior pituitary is not blocked during bovine pregnancy (Fuchs, 1985), the maintenance of gestation despite high concentrations of oxytocin receptor in the uterine tissues is perplexing. The present study was conducted to improve understanding of this apparent paradox. Since in the previous study (Fuchs et al., 1992) only intercaruncular endometrium and myometrium were examined, the purpose of the present study was to measure oxytocin receptor concentrations in the endometrium of the caruncles, fetal cotyledons and the fetal membranes at various stages of gestation and during parturition.

\section{Materials and Methods}

\section{Animals}

Tissues from 38 Hereford and Angus cows from USDA Sub-tropical Agricultural Research Station, Brookville, Florida were used in this study. The cows were mated with fertile bulls and kept on pasture until the designated day of tissue collection. Groups of three to five cows were slaughtered on days $20,50,100,150,200,230,250,275,280$ to 284 of gestation, during labour and within $24 \mathrm{~h}$ after calving. Mean duration of gestation in these breeds of cows is 284 days. To obtain a group of cows as close to term as possible but not yet in labour, a number of cows were examined daily from day 280 onwards for changes in udder, teats, vulva, cervix and pelvic ligaments for indications of impending parturition, and slaughtered when they were judged to be within 12 to $36 \mathrm{~h}$ of calving. Four cows slaughtered on days 280 to 284 of gestation constituted the group considered to be at term (day $282 \pm 1$ ), and five cows with visible signs of labour and with cervix dilated from $17 \mathrm{~cm}$ to full dilation constituted the labour group. Eight of the pregnant cows were obtained from the local slaughterhouse and the duration of gestation was determined from fetal crown rump length (Winters et al., 1942). All cows were stunned by a blow on the head, exsanguinated and the uterus and its contents removed as quickly as possible. The uterus was opened; intercaruncular and caruncular endometrium were dissected free from myometrium; fetal cotyledons and pieces of amnion and chorioallantois were dissected out and frozen on dry ice. The tissues were kept at $-80^{\circ} \mathrm{C}$ until processed for receptor assay. Intercaruncular and caruncular endometrium were also obtained from two nonpregnant cows at oestrus.

\section{Tissue preparation}

Tissue (2-3 g) was pulverized while still frozen, homogenized using 4-5s bursts with a Polytron followed by four up and down strokes in a glass tissue grinder $(30 \mathrm{ml}$, Kontes, Vineland, NJ, USA). The homogenization buffer consisted of $10 \mathrm{mmol}$ Trizma $\mathrm{HCl}]^{-1}, 1.5 \mathrm{mmol}$ EDTA $1^{-1}, 0.5 \mathrm{mmol}$ dithiothreitol $1^{-1}$ and 1 mmol phenylmethylsulfonyl fluoride $1^{-1}$ (PMSF), $\mathrm{pH} 7 \cdot 5$. The crude microsomal pellet precipitated between $1000 \mathrm{~g}(10 \mathrm{~min})$ and $160000 \mathrm{~g}$ $(30 \mathrm{~min})$ was used in all assays. The pellets were washed and suspended for storage in $\mathrm{Ca}^{2+}$-free Hank's salt solution containing $1 \mathrm{mmol} P M S F 1^{-1}$ at concentrations of 5 to $20 \mathrm{mg}$ protein $\mathrm{ml}^{-1}$. All procedures were carried out on ice or at $4^{\circ} \mathrm{C}$. Protein assays were performed according to Lowry et al. (1951) using BSA as a standard. The interassay variation was $6.7 \%$ in 10 assays. Intra-assay variation was less than $5 \%$. All chemicals were purchased from Sigma (St Louis, MO, USA).

\section{Receptor assay}

The receptor assays were carried out as previously described, using a concentration of $1 \mathrm{mg}$ membrane protein $\mathrm{ml}^{-1}$ in all instances (Fuchs et al., 1991). The total assay volume was $0.22 \mathrm{ml}$ for endometrium and caruncles, and $0.33 \mathrm{ml}$ for cotyledons, amnion and chorioallantois. A larger volume rather than a greater concentration of protein 
was used for the tissues with a lower specific binding because nonspecific binding increased nonlinearly at higher protein concentrations. Intercaruncular and caruncular endometrium from the same cow were always measured in the same assay. The labelled ligand was $\left[{ }^{3} \mathrm{H}\right]$ oxytocin from New England Nuclear (Boston, MA, USA), with a specific activity of $37.7 \mathrm{Ci} \mathrm{mmol}^{-1}$. Scatchard plots were constructed with 4-7 different concentrations of labelled ligand varying from $1 \times 10^{-10}$ to $5 \times 10^{-8} \mathrm{~mol} 1^{-1}$. Nonspecific binding was determined in the presence of $1.1 \times 10^{-6} \mathrm{~mol}$ unlabelled oxytocin $1^{-1}$ (Bachem, Torrance, CA, USA). Incubation was at $22^{\circ} \mathrm{C}$ for $60 \mathrm{~min}$ and separation of bound and free ligand was by rapid filtration through Whatman GF/F glassfibre filters using a Braendel (Gaithersburg, MD, USA) cell harvester. The dry filters were counted in a Beckman liquid scintillation counter using $5 \mathrm{ml}$ Cytocint (ICN/ Schwartz/Mann, Cleveland, OH, USA) at an efficiency of $40 \%$. Mean interassay variation was $7.7 \%$ in 15 duplicate Scatchard plots. To assess the specificity of the binding sites displacement experiments with cold oxytocin and competition experiments with the following analogues were performed in the presence of $\left.5 \times 10^{-10} \mathrm{~mol}^{3} \mathrm{H}\right]$ oxytocin $\mathrm{I}^{-1}$ : arginine vasopressin (AVP); a specific oxytocin antagonist, [1- $\beta$-mercapto- $\beta, \beta$-cyclopenta-methylene-propionic acid), 2-( $O$-methyl)-tyrosine, 8-ornithine, 9-tyrosine amide]vasotocin (OTA); a specific vasopressor ( $\mathrm{VP}_{1}$ receptor) agonist, [2-phenylalanine, 3-isoleucine, 8-ornithine] vasopressin (Phe-Orn-VT); and a $\mathrm{VP}_{1}$ receptor antagonist[1-( $\beta$-mercapto$\beta, \beta$-cyclopenta-methylene propionic acid), 2-( $O$-methyl)-tyrosine, 8-argininelvasopressin $\left(\mathrm{d}\left(\mathrm{CH}_{2}\right)_{5}\right.$-Tyr-Me-AVP). The analogues were obtained from M. Manning, Medical College of Ohio, Toledo, OH, USA.

\section{Statistical analysis}

Data were analysed with an iterative nonlinear computerized curve fitting program (LIGAND) from Biosoft (Elsevier, Cambridge, UK) which gave the parameters $K_{\mathrm{a}}, K_{\mathrm{d}}$ and $B_{\max }$. Because Cochrans C test indicated heteroscedacity of the data, the values for binding capacity were subjected to logarithmic transformation which resulted in homogeneity of variance. Regression analysis and one-way ANOVA were performed with the data from each tissue. To assess differences between groups, multiple range testing with the least significant difference procedure was performed. The $K_{\mathrm{d}}$ values of different tissues were compared by Student's $t$-test, values for caruncular and intercaruncular endometrium, caruncles and cotyledons; chorioallantois and amnion were compared by paired $t$-test (Zar, 1974). The data shown are mean \pm SEM unless otherwise indicated, $P<0.05$ was considered significant.

\section{Results}

\section{Endometrial intercaruncular and caruncular receptors}

Caruncular endometrium, like intercaruncular endometrium, had high-affinity saturable binding sites for $\left[{ }^{3} \mathrm{H}\right]$ oxytocin. The binding data fitted a single site model in both tissues. The caruncular receptor sites had significantly higher affinity, $K_{\mathrm{d}}=5.43 \pm 0.22 \times 10^{-10} \mathrm{~mol} \mathrm{l}^{-1}$, than intercaruncular endometrium, $K_{\mathrm{d}}=9 \cdot 1 \pm 0.69 \times 10^{-10} \mathrm{~mol} \mathrm{l}^{-1}(P<0.001)$. Cold oxytocin and a specific oxytocin antagonist (OTA) displaced $\left[{ }^{3} \mathrm{H}\right]$ oxytocin with similar affinity to labelled oxytocin, whereas arginine vasopressin and a specific vasopressor agonist (Phe-Orn-VT) and antagonist $\left(\mathrm{d}\left(\mathrm{CH}_{2}\right)_{5}\right.$-Tyr-Me-AVP) displaced $\left[{ }^{3} \mathrm{H}\right]$ oxytocin with three to eight times lower affinities, indicating the specificity of the binding sites. The affinities did not change in the course of pregnancy and parturition, whereas the binding capacity increased significantly in all tissues $(P<0.002$ to 0.0001 in regression analysis). Intercaruncular oxytocin receptor concentrations rose progressively from $39 \pm 11 \mathrm{fmol} \mathrm{mg}^{-1}$ protein on day 20 to term, whereas caruncular receptor concentrations remained low throughout most of gestation (mean: $145 \pm 24.4 \mathrm{fmol} \mathrm{mg}^{-1}$ protein), and rose only at the end of gestation (Fig. 1). A marked increase in receptor concentrations was observed in both tissues at term, before the cows showed any clinical signs of labour. The caruncular oxytocin receptor concentrations had tripled (mean: $438 \pm 90 \mathrm{fmol} \mathrm{mg}^{-1}$ ) on day $282 \pm 1$ and during active labour they had risen fivefold $\left(727 \pm 163 \mathrm{fmol} \mathrm{mg}^{-1}\right)$. The intercaruncular endometrial receptor concentrations, which had reached a plateau of about $4500 \mathrm{fmol} \mathrm{mg}^{-1}$ between days 250 and 275 , increased by about $50 \%$ shortly before the onset of labour to $7300 \pm 1418 \mathrm{fmol} \mathrm{mg}^{-1}$ on day $282 \pm 1$, with no further rise during labour.

Caruncular endometrium differs morphologically somewhat from intercaruncular endometrium being devoid of glandular tissue, and the caruncles are also discernible in nonpregnant cows. To examine whether the ability of caruncular endometrium for oxytocin receptor formation differs substantially from that of intercaruncular endometrium, we collected several caruncles and intercaruncular endometrium from two nonpregnant cows slaughtered 21 days after oestrus, when high 


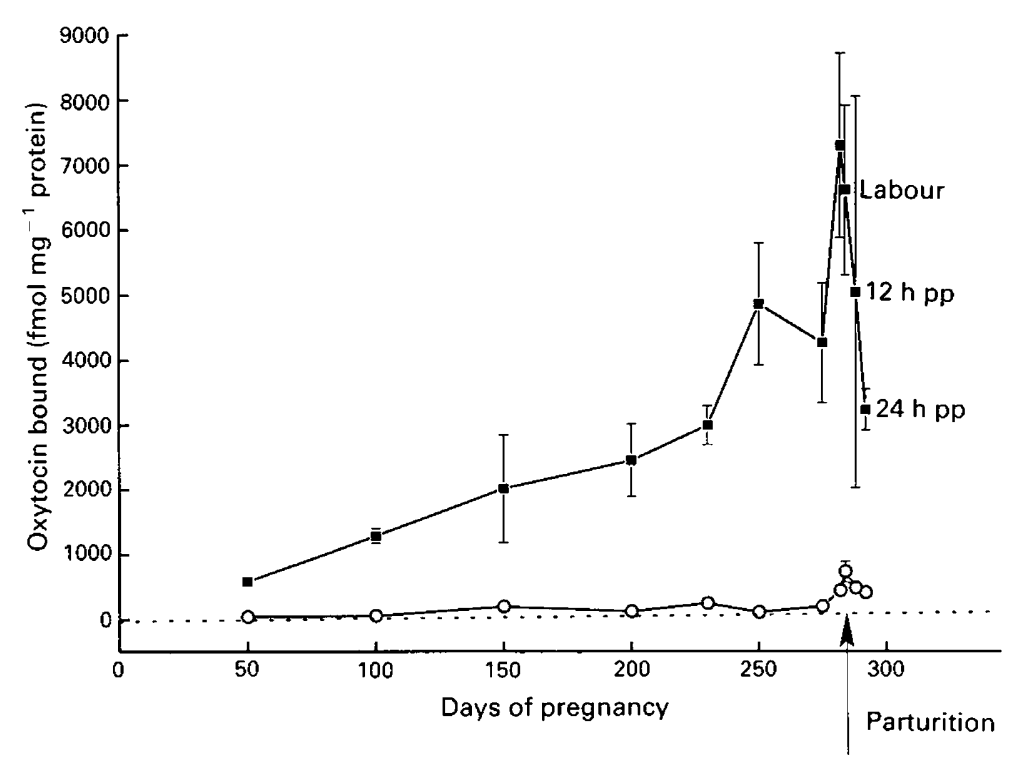

Fig. 1. Changes in intercaruncular $(\boldsymbol{\square})$ and caruncular $(O)$ endometrial oxytocin receptor concentrations during pregnancy and parturition in cows. Values are means $\pm \operatorname{SEM}(n=3-5)$. SEM bars for caruncular values are too small to show. pp: postpartum.

concentrations of oxytocin receptors are present in the intercaruncular endometrium (Fuchs et al., 1992). The concentration of oxytocin receptors were similar in the two types of tissue, intercaruncular: $4296 \pm 241 \mathrm{fmol} \mathrm{mg}^{-1}\left(K_{\mathrm{d}}=1.4 \times 10^{-10} \mathrm{~mol} \mathrm{l}^{-1}\right)$ and caruncular: $3916 \pm 227 \mathrm{fmol} \mathrm{mg}^{-1}$ $\left(K_{\mathrm{d}}=9.3 \times 10^{-10} \mathrm{~mol} \mathrm{1}^{-1}\right)$; the differences were not significant $(P<0 \cdot 5)$.

\section{Fetal placenta and membranes}

The cotyledons also had specific oxytocin-binding sites, which had similar affinity to the caruncular binding sites, mean $K_{\mathrm{d}}: 5.96 \pm 0.45 \times 10^{-10} \mathrm{~mol} 1^{-1}$. Receptor affinity in the cotyledons and caruncles was significantly higher than that in the intercaruncular endometrium $(P<0.001)$. As in the endometrium, binding data for fetal placenta and membranes fitted a single site model. No change in receptor affinity was observed in the course of pregnancy. The oxytocin receptor concentrations in the cotyledons were very low, mean $16.5 \pm 7 \mathrm{fmol} \mathrm{mg}^{-1}$ from day 50 to 200 . On days 230,250 and 275 the concentrations had increased to $73 \pm 25 \mathrm{fmol} \mathrm{mg}^{-1}$ on average, and during labour and early post partum to a mean of $152 \pm 26 \mathrm{fmol} \mathrm{mg}^{-1}$ protein (Fig. 2). Maternal caruncular oxytocin receptor concentrations were higher than those in fetal cotyledons at all times.

Amnion and chorioallantoic membranes also had very low numbers of oxytocin receptors throughout most of gestation, ranging from 5 to $66 \mathrm{fmol} \mathrm{mg}^{-1}$, mean $19.1 \pm 4.6 \mathrm{fmol}_{\mathrm{mg}^{-1}}$ protein (Fig. 3). Receptor affinities in the two types of tissue were similar and significantly lower than those in the caruncles and cotyledons and not different from the affinity of intercaruncular endometrial receptors; the mean $K_{\mathrm{d}}$ in the amnion was $8.27 \pm 0.56 \times 10^{-10} \mathrm{~mol}^{-1}$ and the mean $K_{\mathrm{d}}$ in the chorioallantois was $8.73 \pm 0.62 \times 10^{-10} \mathrm{moll}^{-1}$. At term the receptor concentrations in both amnion and chorioallantois rose abruptly, and were $135 \pm 40$ and $120 \pm 60 \mathrm{fmol} \mathrm{mg}^{-1}$ protein, respectively, on day $282 \pm 1$. During labour, the receptor concentrations in the fetal membranes had increased further being $365 \pm 185 \mathrm{fmol} \mathrm{mg}^{-1}$ protein in amnion and $278 \pm 85 \mathrm{fmol}$ $\mathrm{mg}^{-1}$ protein in chorioallantois. There was no significant difference between the two types of membrane at any time studied. However, the two types of fetal membrane had different concentrations of crude membrane protein per unit wet weight of tissue (Table 1), and the oxytocin 


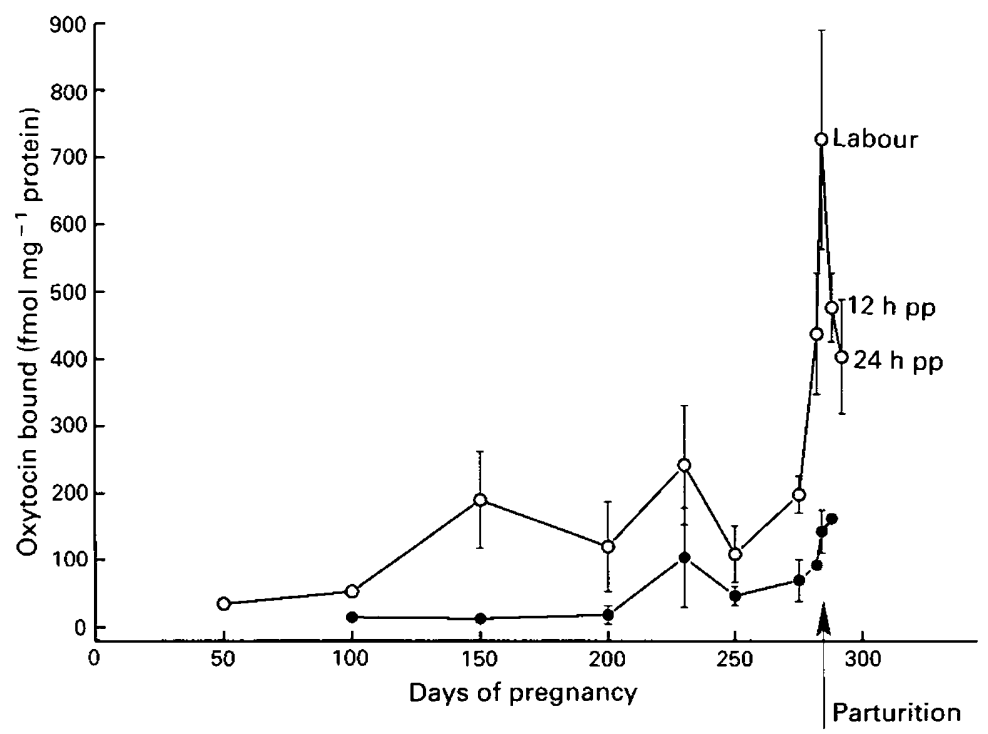

Fig. 2. Concentrations of oxytocin receptors in caruncular endometrium $(O)$ and fetal cotyledons $(0)$ during pregnancy and parturition of the same cows as in Fig. 1. Values are means $\pm \operatorname{SEM}(n=3-5)$. (Note difference in scale from Fig. 1.)

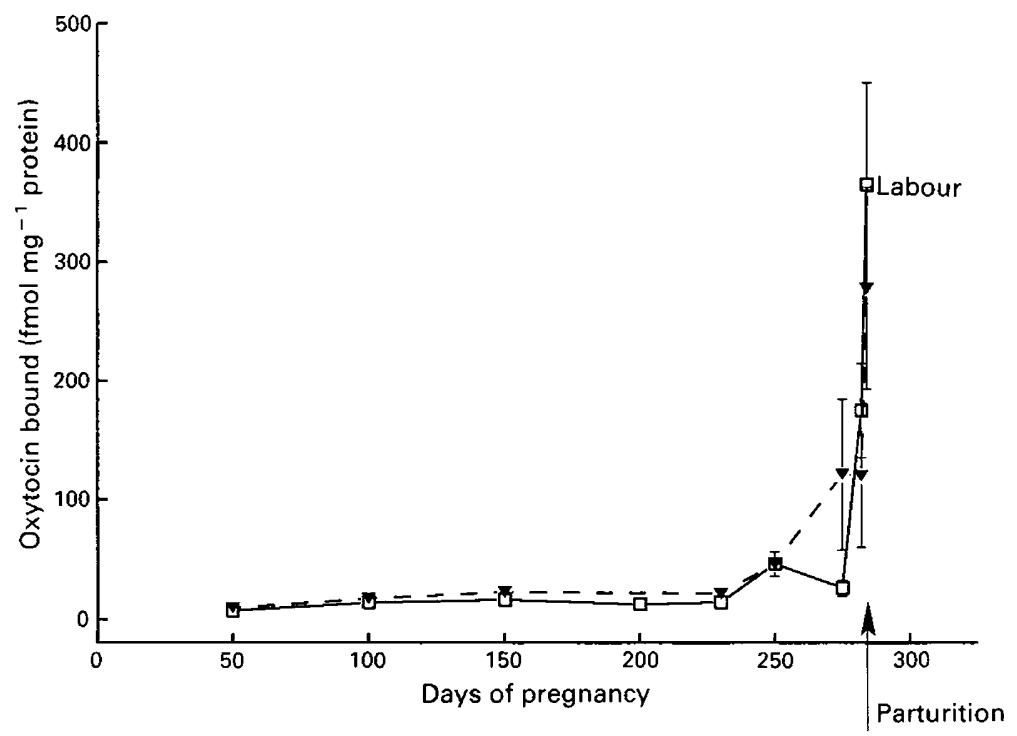

Fig. 3. Concentrations of oxytocin receptors in chorioallantoic $(\boldsymbol{\nabla})$ and amniotic membranes $(\square)$ of pregnant cows during pregnancy and parturition in the same cows as in Fig. 1. Values are means \pm SEM.

receptor concentrations per unit wet weight of tissue therefore also differed. Expressed as oxytocin receptor content $\mathrm{g}^{-1}$ wet weight of tissue the values for the three fetal tissues during labour were on average: chorioallantois, $940 \mathrm{fmol} \mathrm{g}^{-1}$; amnion, $310 \mathrm{fmol} \mathrm{g}^{-1}$ and fetal cotyledons, $714 \mathrm{fmol} \mathrm{g}^{-1}$. The values in intercaruncular endometrium, $37230 \mathrm{fmol} \mathrm{g}^{-1}$, were about five times the values in caruncles, $7160 \mathrm{fmol}^{-1}$, in contrast to ten times the value when expressed in $\mathrm{fmol} \mathrm{mg}^{-1} \mathrm{protein}$ 
Table 1. Contents of crude membrane protein in the fraction precipitated between $100 \mathrm{~g}$ and $160000 \mathrm{~g}$

\begin{tabular}{lc}
\hline Tissue & $\begin{array}{c}\text { Crude membrane fraction protein } \\
\left(\mathrm{mg} \mathrm{g}^{-1} \text { wet weight of tissue) }\right.\end{array}$ \\
\hline Intercaruncular endometrium & $6 \cdot 59 \pm 0.336$ \\
Caruncular endometrium & $10.07 \pm 0.355$ \\
Fetal cotyledons & $5 \cdot 32 \pm 0.384$ \\
Chorioallantois & $3 \cdot 30 \pm 0.337$ \\
Amnion & $0.90 \pm 0.090$ \\
\hline
\end{tabular}

Values are means \pm SEM, for all pregnant and parturient cows (post partum cows excluded).

Differences between all tissues are significant, $P<0.001$ (ANOVA).

Table 2. Oxytocin receptor concentrations in the two uterine horns of pregnant cows 205-240 days after mating. The ipsilateral horn contained the fetus

\begin{tabular}{lcc}
\hline & \multicolumn{2}{c}{$\begin{array}{c}\text { Oxytocin receptors } \\
\text { (fmol mg }\end{array}$} \\
\cline { 2 - 3 } Tissue & Contein) \\
\hline Intercaruncular endometrium & $2597 \pm 748$ & $2488 \pm 995$ \\
Caruncular endometrium & $44 \cdot 0 \pm 11$ & $41 \cdot 3 \pm 8 \cdot 3$ \\
Cotyledons & $32 \cdot 7 \pm 16$ & $71 \cdot 0 \pm 54$ \\
\hline
\end{tabular}

Values are means $\pm \operatorname{SEM}, n=3$.

Table 3. Correlation coefficients between the concentration of oxytocin receptors in uterine tissues and plasma unconjugated oestrone, oestradiol and progesterone in pregnant and parturient cows

\begin{tabular}{lccc}
\hline & \multicolumn{3}{c}{$r$ values } \\
\cline { 2 - 4 } Tissue & $\begin{array}{c}\text { Oestrone }+ \\
\text { oestradiol } \\
\left(\mathrm{OE}_{1}+\mathrm{OE}_{2}\right)\end{array}$ & $\begin{array}{c}\text { Progesterone } \\
\left(\mathrm{P}_{4}\right)\end{array}$ & $\left(\mathrm{OE}_{1}+\mathrm{OE}_{2}\right): \mathbf{P}_{4}$ \\
\hline Intercaruncular endometrium $(n=40)$ & 0.6318 & -0.3770 & 0.5160 \\
$P$ & $<0.001$ & 0.02 & $<0.001$ \\
Caruncular endometrium $(n=32)$ & 0.5100 & -0.5600 & 0.8375 \\
$P$ & $<0.005$ & $<0.001$ & $<0.001$ \\
Cotyledons $(n=25)$ & 0.0513 & -0.5676 & 0.5469 \\
$P$ & not significant & $<0.005$ & $<0.02$ \\
\hline
\end{tabular}

Values are calculated by simple linear regression analysis.

With the exception of chorioallantois and fetal cotyledons that had similar receptor contents per $\mathrm{g}$ wet weight, the values for all tissues were significantly different (ANOva, $P<0 \cdot 01$ ).

In three pregnant cows at 205, 206 and 240 days of gestational age oxytocin receptor concentrations were measured in the intercaruncular and caruncular endometrium as well as in fetal cotyledons from both the ipsi- and contralateral horn. No difference in receptor concentration was observed between the two horns (Table 2).

The concentrations of plasma unconjugated oestrone, oestradiol and progesterone were measured in samples taken from all experimental cows at slaughter (Fuchs et al., 1992); and the 
correlation coefficients between these values and tissue oxytocin receptor concentrations (fmol $\mathrm{mg}^{-1}$ protein) were calculated (Table 3 ). The correlation coefficients for the receptors in fetal cotyledons were similar to those in fetal membranes (values not shown). A highly significant $(P<0.001)$ inverse correlation with plasma progesterone was observed for oxytocin receptors in caruncles, cotyledons and fetal membranes; the correlation with intercaruncular receptor concentrations was much weaker, $r: 370, P=0 \cdot 02$. The correlations of plasma-free oestrogens with oxytocin receptor concentrations in the maternal tissues were highly significant but were not significant in fetal tissues.

\section{Discussion}

Considering the very high oxytocin receptor concentrations in intercaruncular endometrium, the paucity of these receptors in the caruncular endometrium during most of gestation is remarkable. There are $40-60$ such caruncles rather evenly distributed over both the pregnant and nonpregnant horns of the uterus, and they constitute a significant proportion of the total endometrial surface area. Oxytocin has been shown to stimulate prostaglandin $E_{2}$ and $F_{2 \alpha}$ from cow endometrium (Lafrance \& Goff, 1990). The release of oxytocin from the neurohypophysis is not inhibited during pregnancy in cows but is maintained in a pulsatile manner (Fuchs, 1985). The lack of oxytocin receptors renders the caruncles and cotyledons unable to respond to oxytocin stimulation before term and this may provide an explanation for why labour does not start prematurely, particularly since caruncles and cotyledons are thought to be the main sites of prostanoid production in parturient cows (Guilbault et al., 1984; Gross et al., 1987). The prostaglandins are much less potent uterotonic agents than oxytocin, but they have a marked potentiating effect on oxytocin-induced contractions (Coleman \& Parkington, 1988; Quartero et al., 1991). Indeed, Gillette (1966) observed significantly more uterine activity in interplacental than in placental locations one to six days before parturition, whereas on the day of calving there were no differences. Oxytocin has also been shown to release endothelin, a strong vasoconstricting agent, from endometrial cells (Orlando et al., 1990). The absence of oxytocin receptors in the bovine caruncles and cotyledons before term may therefore assure unhindered blood flow to the caruncles during pregnancy.

It should be emphasized that although low in comparison to intercaruncular endometrium, the receptor concentrations in the tissues of the placentomes and membranes at term are similar to the concentrations in rat myometrium during labour (Soloff et al., 1979). The low concentrations of oxytocin receptors in these tissues during most of gestation were anticipated, but the significant rise in all three tissues at term was surprising, and has not yet been described in other species. Fetal membranes and placenta have not been considered target tissues for oxytocin. However, oxytocin has been shown to stimulate the release of prostaglandins from explants of human amnion at term in a dose-dependent manner (Fuchs et al., 1981) and from primary cultures of human amniotic epithelial cells obtained from the fetal membranes of patients at term (Mitchell \& Lundin-Schiller, 1990). These observations provide evidence for a functional role for the receptors in fetal membranes. Endogenous oxytocin is secreted in large amounts into the maternal circulation during bovine parturition (Landgraf et al., 1983; Fuchs, 1985). Because of the high oxytocin receptor density prevailing in all intrauterine tissues at the onset of labour, oxytocin may be the agent responsible for the release of prostaglandin $\mathrm{F}_{2 \alpha}\left(\mathrm{PGF}_{2 \alpha}\right)$ from the uterus during active labour as observed by numerous authors. The concentrations of $\mathrm{PGF}_{2 \alpha}$ in the uterine venous blood begin to rise significantly about $12 \mathrm{~h}$ before calving (Hunter et al., 1977; Eley et al., 1981). This rise coincides with the increases in oxytocin receptor concentrations in fetal membranes, placentomes and intercaruncular endometrium reported here. It is therefore possible that endogenous oxytocin is a mediator of the preparturient release of uterine $\mathrm{PGF}_{2 \alpha}$ which in turn may cause the abrupt fall in plasma progesterone on the last day before calving, the final event that precipitates labour in cows (Stabenfeldt et al., 1970; Hunter et al., 1977; Eley et al., 1981). 
The factors that control the formation of oxytocin receptors during pregnancy in cows remain to be elucidated. Endometrial oxytocin receptor concentrations in nonpregnant and early pregnant cows showed a strong negative correlation with circulating plasma progesterone concentrations suggesting that progesterone inhibits their formation (Meyer et al., 1988; Fuchs et al., 1990; Jenner et al., 1991). The present results indicate that intercaruncular endometrium overcomes the inhibitory effects of progesterone on oxytocin receptor formation relatively early in gestation, whereas caruncular endometrium and cotyledons remain strongly suppressed throughout pregnancy. Fetal cotyledons may therefore provide factors that in a paracrine fashion maintain the progesteroneinduced suppression in the neighbouring caruncular cells. The sharp fall in plasma progesterone at term and the rise in maternal plasma unconjugated oestrone and oestradiol concentrations during the last week of gestation (Robertson, 1974; Hunter et al., 1977; Eley et al., 1981; Fuchs et al., 1992) may be responsible for the preparturient increases in oxytocin receptor concentrations observed during the last few days before calving in all intrauterine tissues. However, the lack of correlation between circulating unconjugated oestrogens and receptor concentrations in fetal cotyledons and fetal membranes, in view of strong correlation with receptors in endometrial tissues, is striking and indicates differential regulation of oxytocin receptors in maternal and fetal tissues.

We conclude that oxytocin receptor concentrations in the intercaruncular and caruncular endometrium are regulated in different ways during pregnancy. The former is likely to be under maternal systemic control, and the latter under paracrine control by fetal factors that prevent oxytocin receptor formation until term. Shortly before the onset of labour, oxytocin receptor concentrations rise steeply in all intrauterine tissues. We have previously found that circulating oxytocin concentrations are significantly increased during labour. Together these observations provide strong support for the view that endogenous oxytocin plays an integral role in parturition in cows.

We thank Warner Lambert Foundation and United States-Israel Binational Agricultural and Developmental Fund (US-1160-86C) for financial support; A. Hammond and L. Adams, United States Agricultural Research Station for providing the cows, T. Brian for use of Central Packing Co., Florida, for tissue collection, and L. Eubanks at the University of Florida Meat Laboratory for the processing of animals for tissue collection. The excellent technical assistance of D. Navarro and K. S. Carano is acknowledged. This is Journal Series No. R-02710 of the Florida Agricultural Experiment Station.

\section{References}

Coleman, H.A. \& Parkington, H. (1988) Induction of prolonged excitability in myometrium of pregnant guinea pig by prostaglandin $\mathrm{F}_{2 a}$. Journal of Physiology (London) 399, 33-47.

Eley, D.S., Thatcher, W.W., Head, H.H., Collier, R.J. \& Wilcox, C.J. (1981) Periparturient endocrine changes of conceptus and maternal units in Jersey cows bred for milk yield. Journal of Dairy Science 64, 296-311.

Fitzpatrick, R.J. (1960) The reactivity of the ruminant uterus to posterior pituitary hormones. Journal of Comparative Pathology and Therapeutics 70, 36-58.

Fuchs, A.R. (1985) Oxytocin in animal parturition. In Oxytocin, Clinical and Laboratory Studies, pp. 207235. Eds J. A. Amico \& A. G. Robinson. Elsevier Science Publishers BV, Amsterdam.

Fuchs, A.R. (1990) Oxytocin and oxytocin receptors: maternal signals for parturition. In Uterine Contractility: Mechanisms of Control, pp. 177-190. Ed. R. E. Garfield. Serono Symposia, Norwell.

Fuchs, A.R., Husslein, P. \& Fuchs, F. (1981) Oxytocin and the initiation of human parturition. II. Stimulation of prostaglandin production in human decidua by oxytocin. American Journal of Obstetrics and Gynecology 141, 694-697.

Fuchs, A.R., Periyasamy, S., Alexandrova, M. \& Soloff, M.S. (1983) Correlation between oxytocin receptor concentration and responsiveness to oxytocin in pregnant rat myometrium. Effect of ovarian steroids. Endocrinology 113, 742-749.

Fuchs, A.R., Behrens, O., Helmer, H., Liu, C.H., Barros, C.M. \& Fields, M. (1990) Oxytocin and vasopressin receptors in bovine endometrium and myometrium during the estrous cycle and early pregnancy. Endocrinology 127, 629-636.

Fuchs, A.R., Helmer, H., Behrens, O., Antonian, L., Liu, C.H., Chang, S.M. \& Fields, M. Oxytocin and bovine parturition: a steep rise in endometrial oxytocin receptors precedes onset of labor. Biology of Reproduction (in press).

Gillette, D.D. (1966) Placental influence on uterine activity in the cow. American Journal of Physiology 211, 1095-1098.

Gross, T.C., William, W.F., Manspeaker, J.E. \& Lewis, G.S. (1987) Bovine placental prostaglandin synthesis 
in vitro as it relates to placental separation. Prostaglandins 34, 903-917.

Guilbault, L.A., Thatcher, W.W., Foster, D.B. \& Caton, D. (1984) Relationship of prostaglandin $\mathbf{F}_{2 a}$ metabolite concentrations in peripheral plasma with local uterine production of $\mathrm{F}$ series prostaglandins and changes in uterine blood flow during the early postpartum period in cattle. Biology of Reproduction 31, 870-878.

Hunter, J.T., Fairclough, R.J., Peterson, A.J. \& Welch, R.A.S. (1977) Fetal and maternal hormonal changes preceding normal bovine parturition. Acta Endocrinologica 84, 653-662.

Jenner, L.J., Parkinson, T.J. \& Lamming, G.E. (1991) The uterine oxytocin receptor in the cyclic and early pregnant cow. Journal of Reproduction and Fertility 91, 49-58.

LaFrance, M. \& Goff, A.K. (1990) Control of uterine $\mathrm{PGF}_{2 a}$ release in vitro. Biology of Reproduction 42, 288-293.

Landgraf, R., Schulz, J., Eulenberger, K. \& Wilhelm, J. (1983) Plasma levels of oxytocin and vasopressin before, during and after parturition in cows. Experimental and Clinical Endocrinology 81, 321-328.

Leavitt, W.W. (1985) Hormonal regulation of myometrial estrogen, progesterone and oxytocin receptors in the pregnant and pseudo-pregnant hamster. Endocrinology 116, 1079-1084.

Lowry, O.H., Rosebrough, N.L., Farr, A.L. \& Randall, R.L. (1951) Protein measurements with the folin phenol reagent. Journal of Biological Chemistry 193, 265-275.

Meyer, H.H.D., Mittermeier, T. \& Schams, D. (1988) Dynamics of oxytocin, estrogen and progestin receptors in the bovine endometrium during the estrous cycle. Acta Endocrinologica 118, 96-104.

Mironneau, J. (1976) Effects of oxytocin on ionic currents underlying rhythmic activity and contraction in uterine smooth muscle. Pflügers Archiv European Journal of Physiology 363, 113-118.

Mitchell, M.D. \& Lundin-Schiller, S. (1990) The regulation of arachidonic acid metabolism during pregnancy. In Uterine Contractility, pp. 205-220. Ed. R. E. Garfield. Serono Symposia, Norwell.

Nissenson, R., Flouret, G. \& Heckler, O. (1978) Opposing effects of estradiol and progesterone on oxytocin receptors in rabbit uterus. Proceedings of the National Academy of Sciences, USA 75, 2044-2048.

Orlando, C., Brandi, M.C., Peri, A., Giannini, S., Fantoni, G., Calabresi, E., Serio, M. \& Maggi, M. (1990) Neurohypophyseal hormone regulation of endothelin secretion from rabbit endometrial cells in primary culture. Endocrinology 126, 1780-1782.

Quartero, H.W.P., Fry, C.H., Noort, W.A. \& Keirse, M.J.N.C. (1991) Role of prostaglandins and leukotrienes in the synergistic effect of oxytocin and corticotrophin releasing hormone. Prostaglandins 42, $137-150$.

Riemer, R.K., Goldfien, A.C., Goldfien, A. \& Roberts, J.M. (1986) Rabbit uterine oxytocin receptors and in vitro contractile response: abrupt changes at term and the role of eicosanoids. Endocrinology 119, 699-709.

Roberts, J.S., McCracken, J.A., Gavagan, G.E. \& Soloff, M.S. (1976) Oxytocin stimulated release of $\mathrm{PGF}_{2 a}$ from ovine endometrium in vitro: correlation with estrous cycle and oxytocin receptor binding. Endocrinology 99, 1107-1114.

Robertson, H.A. (1974) Changes in the concentration of unconjugated oestrone, oestradiol-17 $\beta$ and oestradiol$17 \alpha$ in maternal plasma of the pregnant cow in relation to the initiation of parturition. Journal of Reproduction and Fertility 36, $\mathrm{I}-8$.

Soloff, M.S. (1975) Uterine receptors for oxytocin: effects of estrogens. Biochemical and Biophysical Research Communications 65, 205-212.

Soloff, M.S., Alexandrova, M. \& Fernstrom, M. (1979) Oxytocin receptors: triggers for parturition in the rat? Science 204, 1313-1314.

Stabenfeldt, G.H., Osburn, B.I. \& Ewing, L.L. (1970) Peripheral plasma progesterone levels in the cow during pregnancy and parturition. American Journal of Physiology 218, 571-575.

Winters, L.M., Green, W.W. \& Comstock, R.E. (1942) Prenatal development of the bovine. In Station Bulletin No. 151. Ed. L. A. Etkin. Minnesota Agricultural Experiment Station, University of Minnesota, St Paul, $\mathrm{MN}$.

Zar, J.H. (1974) Biostatistical Analysis, Prentice Hall, Englewood Cliffs.

Received 18 November 1991 